\title{
Effect of Internet Addiction on Sleep Quality, Physical Activity and Cognitive Status Among University Students
}

\section{Üniversite Öğrencilerindeki Internet Bağımlılığının Uyku Kalitesine, Fiziksel Aktiviteye ve Bilișsel Duruma Etkisi}

\author{
(D) Sabriye Ercan, (D) Hüseyin Tolga Acar, (D) Esma Arslan, (D) Ayhan Canbulut, (D) Ahsen Oğul, (D) Cem Çetin
}

Süleyman Demirel University Faculty of Medicine, Department of Sports Medicine, Isparta, Turkey

\begin{abstract}
Objective: While the acceptable use of the internet is beneficial, internet addiction, which is defined as the individual's inability to control Internet use in addition to excessive Internet use, is a clinical condition that has various negative effects, especially on teenagers. The present study aimed to investigate the effect of internet addiction on various parameters like body mass index, physical activity, sleep quality and cognitive status in university students.

Materials and Methods: A total of 1.007 university students were included in the study. The participants were asked to fill in questionnaires prepared by the researchers. Demographic information of the participants was recorded. The International Physical Activity Questionnaire (short form), Internet Addiction Test, Epworth Sleepiness Scale, Pittsburgh Sleep Quality Index and Cognitive Failures Questionnaire were used during face-to-face assessment.

Results: In the Internet Addiction Test, $82.6 \%(n=832)$ of the participants were defined as "normal internet users" who received scores $<50$, whereas $17.4 \%(n=175)$ were defined as "problematic Internet users" with scores $\geq 50$. Problematic internet users had higher body mass index $(p=0.0001)$. In addition, a low-level and positive correlation was observed between poor sleep quality and total and sub-dimension scores in the Cognitive Failures Questionnaire with problematic Internet use.

Conclusion: Internet addiction influences the body mass index, leading to obesity, low sleep quality and cognitive disorders, such as attention and memory problems that may be encountered in daily life.
\end{abstract}

Keywords: Body mass index, cognitive status, internet addiction, physical activity, sleep
Öz

Amaç: Internetin kabul edilebilir bir şekilde kullanılması bireye fayda sağlarken, aşırı internet kullanımına ek olarak bireyin internet kullanımını kontrol edememesi olarak tanımlanan internet bağımlılı̆ı ise özellikle genç yaş grubunda yer alan bireyler üzerinde çeşitli olumsuz etkileri olan klinik bir durumdur. Bu çalışmada, gençlerde internet bağımlılığının vücut kitle indeksine, fiziksel aktiviteye, uyku kalitesine ve bilişsel duruma etkisini incelemek amaçlanmıştır.

Gereç ve Yöntem: Çalışmaya üniversitemizde eğitim-öğretim gören 1,007 öğrenci dahil edilmiştir. Katılımcılardan tarafımızca hazırlanan anketlerin cevaplanması istenmiştir. Hazırlanan anketlerle katılımcıların, demografik verileri alınmış ve ardından katılımcılara Uluslararası Fiziksel Aktivite Anketi (kısa form), Internet Bağımlılık Testi, Epworth Uykululuk Ölçeği, Pittsburgh Uyku Kalitesi Ölçeği ve Bilişsel Durum Ölçeği gibi ölçekler yüz yüze anket doldurma tekniği ile uygulanmıştır.

Bulgular: Öğrencilerin \%82,6'sı (n=832) İnternet Bağımlılık testinden 50 puanın altında alarak "ortalama kullanıcı" olarak tanımlanırken \%17,4'ü ( $n=175) 50$ puan ve üstünden puan alarak "problemli kullanıcı" olarak tanımlanmıştır. Çalışmamızın sonuçlarına göre problemli kullanıcı grubundaki katılımcılar daha yüksek vücut kitle indeksi değerlerine sahiptir $(p=0,0001)$. Ayrıca uyku kalitesinin düşüklüğü, Bilişsel Durum Ölçeğindeki toplam ve alt boyut puanları ile problemli internet kullanımı arasında pozitif yönlü düşük düzeyde ilişkisi tespit edilmiştir.

Sonuç: Elde edilen veriler neticesinde internet bağımlılığı, vücut kitle indeksini etkileyerek dolayısıyla obeziteye, düşük uyku kalitesine ve günlük hayatta karşılaşılabilecek dikkat ve hafıza sorunları gibi bilişsel bozukluklara neden olmaktadır.

Anahtar Kelimeler: Beden kitle indeksi, bilişsel durum, internet bağımlılı̆ı, fiziksel aktivite, uyku 


\section{Introduction}

Although it has been designed for the purpose of facilitating the quest for information, interpersonal communication, and commercial operations when initially discovered, the Internet technology is in the center of many users' lives and has become an environment difficult to resist nowadays. The internet, which is undoubtedly one of the most important elements of the digital era, has affected the economic, social, scientific, artistic areas, and several others and paved the way for their transformation. Human beings, who would not be able to maintain a lifestyle isolated from these areas, have been influenced by this transformation process (1). In a study conducted by the Turkish Statistical Institute, the rate of internet use was found to be $61.2 \%$ in individuals in the age group of 16-74 in our country. Of these individuals, $82.4 \%$ use the Internet for having a social media profile, sending a message or sharing contents such as photographs, $74.5 \%$ use it for watching videos, $69.5 \%$ for reading news, newspapers or journals, $65.9 \%$ for searching information about health, and $63.7 \%$ for listening to music (2). Young people, who actively participate in physical activity, are less interested in stationary activities such as spending long hours on the Internet. It has been revealed in studies that the computer and internet use at an addictive level cause many negative physical effects on individuals $(3,4)$. One of these negative effects is the health problem called excessive weight gain or obesity. All people need to be nourished in an adequate and balanced way so that they can develop physically, mentally, and socially and be healthy and productive. Obesity, which leads to the most serious health problems resulting from unbalanced nutrition, is a pathological condition characterized by the storage of the energy received more than required for optimal body functioning (5). Furthermore, physical activity and exercise play a crucial role in the prevention of obesity and other health-related problems (6). The main reason behind the apparent increase in the obesity incidence in recent years seems to be the consumption of high-calorie food and the adoption of the accompanying sedentary lifestyle rather than a lifestyle based on the physical activity together with the effect of industrialization. Many studies have put forward the presence of a significant correlation between weight gain and physical inactivity (7-9). Physical inactivity leads to spending less energy than required for a healthy life, and it is considered as a cause of being overweight. Weight gain also forms a vicious cycle resulting in less physical activity (10).

Sleeping is the best way to rest known for humans. After waking up from quality sleep, individuals feel active and ready for a new day. Sleep quality is affected by various factors such as lifestyle, environmental factors, work, social life, economic status, general health status, and stress $(11,12)$. Bad sleep quality is a health problem that can interrupt the continuation of a normal life and lead to other problems. After a long sleeplessness period, a wide range of cognitive problems and angry temperament may arise. Individuals who suffer from insomnia often encounter problems such as difficulty in perception and memory, difficulty in learning, and decreasing risk perception. Moreover, insomnia can increase the risk of cardiovascular diseases, diabetes, and cancer, and thus, contribute to mortality (13). In studies, it has been shown that internet addiction and the intense use of online communication tools among young people affect sleep quality negatively (14-16).

Since the digital technology has reached large masses nowadays, at a time that can be considered recent in terms of history, its effect on users' cognitive functions has not been investigated adequately, and few studies have been conducted on this subject. Despite the findings indicating a possible link between the decrease in attention within the day and the internet use, it is still not clear which mechanism has caused this situation to appear. In few studies, it was revealed that individuals with problematic internet use experienced more impulse control disorders, attention deficit, and forgetfulness in their daily lives (17-19). However, it should be remembered that individuals with underlying behavioral disorders may have a tendency to problematic internet use, and this kind of cognitive disorders cannot be associated only with internet addiction (18).

Based on the hypothesis that problematic internet use will cause an increase in the Body Mass index and have adverse effects on sleep quality and cognitive status, this study aims to investigate the effect of internet addiction on Body Mass index, physical activity, sleep quality, and cognitive status in young people studying at our university.

\section{Materials and Methods}

\section{Participants and study design}

Young people studying at our university in the 2019-2020 academic year were included in the study on a voluntary basis. In the power analysis (confidence level 99\%, precision rate 0.05) applied to determine the sample size, it was found that at least 722 students should be reached. The sample group was selected via the stratified randomization method. Those who were aged below eighteen, students at other universities, diagnosed with any mental disorder, diagnosed with a sleep disorder such as narcolepsy, and diagnosed with alcohol, substance, etc. addiction were excluded from the study.

\section{Instruments}

The participants were asked to fill in the questionnaires prepared by the researchers. The demographic information of the participants was recorded. Afterward, the International Physical Activity Questionnaire (IPAQ) (short form), Internet Addiction Test, Epworth Sleepiness Scale (ESS), Pittsburgh Sleep Quality Index (PSQI), and Cognitive Failures Questionnaire (CFQ) were applied through the face-to-face questionnaire filling technique. The students were divided into two groups as "normal internet user" (Group $_{\text {normal }}$ : a score of 20-49) and "problematic internet user" (Group $_{\text {problematic }}$ : a score of 50-100) according to the scores they obtained from the Internet Addiction Test.

\section{Internet Addiction Test}

The Internet Addiction Test is an extended version of the Internet Addiction Diagnostic Questionnaire and consists of 
20 questions graded in the 5-point Likert-type scale varying between 1 (rarely) and 5 (always) (20). This test contains questions such as "When you use the Internet, how often do you notice that you have been using it for a longer time than you have thought?". It was suggested to determine a score of 50 or above as a limit value to indicate problematic internet use and a score of 80 or above as a limit value to indicate pathological use at an addictive level (21).

\section{IPAQ (short form)}

The IPAQ has short and long forms (22). Its short form was primarily designed to determine the physical activity in adults. Its validity and reliability tests were conducted in many countries, and it is used widely. In Turkey, its reliability and validity were tested in the age range of 15-69 (23). The IPAQ evaluates many physical activities. These consist of physical activities in spare time, house and garden activities, work-related physical activities, and physical activities related to transportation (23). In the IPAQ short question paper, the specific types of three out of four abovementioned activities are stated. Walking, moderate-intensity activities, and vigorous-intensity activities constitute these specific types. The questionnaire (short form) is based on the evaluation of at least 10-minute physical activities performed within the last seven days in terms of frequency, duration (minutes) and intensity and the calculation of the spent metabolic equivalent (MET) value. MET indicates the amount of oxygen used by a person while sitting, at rest (3.5 $\mathrm{mL} \mathrm{O}_{2} / \mathrm{kg} / \mathrm{min}$ on average) (24). According to the IPAQ, 8.0 METs are consumed in "vigorous-intensity physical activities," 4.0 METs in "moderate-intensity physical activities," and 3.3 METs are consumed while a person is "walking." When it comes to calculation, the total MET value is obtained by multiplying the MET values from the activity group by minutes and frequency (day). The multiplied values are finally summed, and the total physical activity value is obtained (24). Accordingly, the physical activity levels of people with weekly MET values below 600 are evaluated as "low," of those with values between 601-3.000 as "moderate," and of those with values above 3.000 as "high."

\section{ESS}

The ESS is a test used to indicate daytime sleepiness. It consists of 8 questions in total. Each question is answered by the patient to give a score between 0 and 3 . In this questionnaire, the possibility of the patient to fall asleep in specific situations (for example, while reading a newspaper or book when sitting, watching TV, traveling by a vehicle for 1 hour without a break), on a normal day when he/she is not too tired, is investigated. The scoring method is the same in all the questions. If there is no possibility of falling asleep, 0 is received as a score. If there is a low possibility, 1 is received. If there is a moderate possibility, 2 is received, and if there is a high possibility, 3 is received. If the total score is 10 and above, it indicates the presence of excessive daytime sleepiness. The Turkish validity study of the ESS was carried out, and it was reported that its Turkish version was effective in demonstrating the daytime sleepiness (25).

\section{PSQI}

The PSQI is a questionnaire that evaluates the sleep quality with questions directed under 7 main headings such as subjective sleep quality, sleep latency, sleep duration, habitual sleep efficiency, sleep disorders, use of sleeping aids, and daytime functions. The questions are given scores between 0 and 3; high scores reflect bad sleep quality. Each of the seven main headings is first evaluated within itself. Afterward, the scores of 7 components are summed. If the total score is 5 and above, it is evaluated as bad sleep quality (26).

\section{CFQ}

The CFQ is a scale developed by Broadbent et al. (27) in 1982 and aiming at measuring daily cognitive errors. It is a 25 -item Self-report scale assessing the simple mistakes made within the last 6 weeks and measuring perception (e.g. Are there times when you cannot see something you need in a supermarket although it is there?), memory (e.g. Do you ever forget the names of people?) and motor functionality (e.g. Do you ever bump into anyone?). The answers are graded over the 5-point Likert-type scale $(0=$ never, $1=$ very rarely, $2=$ sometimes, $3=$ often, $4=$ always). The lowest score that can be obtained from the scale is 0 , and the highest score is 100. All the items in the scale are positively correlated with each other. In the validity and reliability studies of the scale, a good internal consistency coefficient $(\leq 0.89)$ and test-retest reliability $(r=0.82)$, and good correlations with other measurements of cognitive errors $(r=0.62)$ were found (27). Moreover, the Turkish version of the CFQ was found to be a reliable, valid, and sensitive tool for evaluating the cognitive status in university students (28).

\section{Ethical statement}

The study was approved at the meeting of the local ethics committee dated 28/11/2019 and with decision number 283 .

\section{Statistical Analysis}

In the data analysis, the SPSS $\vee 23$ package program was used. After the data were analyzed using descriptive statistical methods, the conformity of the data to the normal distribution was investigated with the Skewness-Kurtosis test. The chisquare test and t-test were used for the determination of the difference between the groups. The Pearson Correlation test was applied for the determination of the factors related to internet addiction, and the linear regression analysis was applied for the identification of the factors affected by internet addiction. The $p$-value was considered significant at the level of $<0.05$. The results were presented as frequency $(n)$, percentage (\%), or mean \pm standard deviation.

\section{Results}

One thousand seven students (females: 619, 61.5\%, males: $388,38.5 \%$ ) with a mean age of $21.2 \pm 2.1$ years, height of $169.8 \pm 9.1 \mathrm{~cm}$, body weight of $64.1 \pm 12.9 \mathrm{~kg}$, and Body Mass index of $22.1 \pm 3.3 \mathrm{~kg} / \mathrm{m}^{2}$ participated in the study. Of the students, $5.2 \%(\mathrm{n}=52)$ receive associate's degree education, 92.1\% ( $n=928)$ bachelor's degree education, 2.1\% $(n=21)$ 
master's degree education, and $0.6 \%(n=6)$ receive doctoral education (Table 1).

Of the participants, $99.1 \%(n=998)$ are single. Of them, $89.3 \%$ $(\mathrm{n}=899)$ have no illnesses, and $92.4 \%(\mathrm{n}=930)$ do not take any medication regularly. Of the students, $18.9 \%(n=190)$ stated that they participated in regular physical activity $(49.3 \pm 48$ months). Smoking (3.4 \pm 3.1 pack/year) was detected in $34.2 \%$ $(n=344)$ of the students, and regular alcohol consumption was found in $5.3 \%(n=53)$ of them (Table 1).

The mean MET value was determined to be $2.323 \pm 2.940$ in the IPAQ-short form. According to the physical activity category, $23.5 \%$ of the students were found to be at a sedentary level and $52.6 \%$ at an inadequate physical activity level. The rate of students with an adequate physical activity level is $23.9 \%$ (Table 2).

\begin{tabular}{|c|c|c|c|c|}
\hline BMI $\left(\mathrm{kg} / \mathrm{m}^{2}\right)$ & $22.1 \pm 3.3$ & $21.9 \pm 3.2$ & $23 \pm 3.4$ & $0.0001^{*}$ \\
\hline Gender (M/F), \% (n) & $38.5 \%(388) / 61.5 \%(619)$ & $35.6 \%(296) / 64.4 \%(536)$ & $52.6 \%(92) / 47.4 \%(83)$ & $0.0001^{*}$ \\
\hline $\begin{array}{l}\text { Educational status (A/L/ } \\
\mathrm{G} / \mathrm{D} ; \%)\end{array}$ & $5.2 \% / 92.1 \% / 2.1 \% / 0.6 \%$ & $5 \% / 92.1 \% / 2.2 \% / 0.7 \%$ & $5.7 \% / 92.6 \% / 1.7 \% / 0 \%$ & 0.7 \\
\hline Disease (yes), \% (n) & $10.7 \%(108)$ & $10.5 \%(87)$ & $12 \%(21)$ & 0.5 \\
\hline Drug use (yes), \% (n) & $7.6 \%(77)$ & $7.6 \%(63)$ & $8 \%(14)$ & 0.8 \\
\hline Smoking (yes) & $34.2 \%(344)$ & $31.4 \%(261)$ & $47.4 \%(83)$ & $0.0001^{*}$ \\
\hline $\begin{array}{l}\text { Smoking period (packs/ } \\
\text { year) }\end{array}$ & $3.4 \pm 3.1$ & $3.5 \pm 3.2$ & $3.2 \pm 3$ & 0.5 \\
\hline $\begin{array}{l}\text { Regular alcohol use (yes), } \\
\%(n)\end{array}$ & $5.3 \%(53)$ & $4.6 \%(38)$ & $8.6 \%(15)$ & $0.003^{*}$ \\
\hline
\end{tabular}

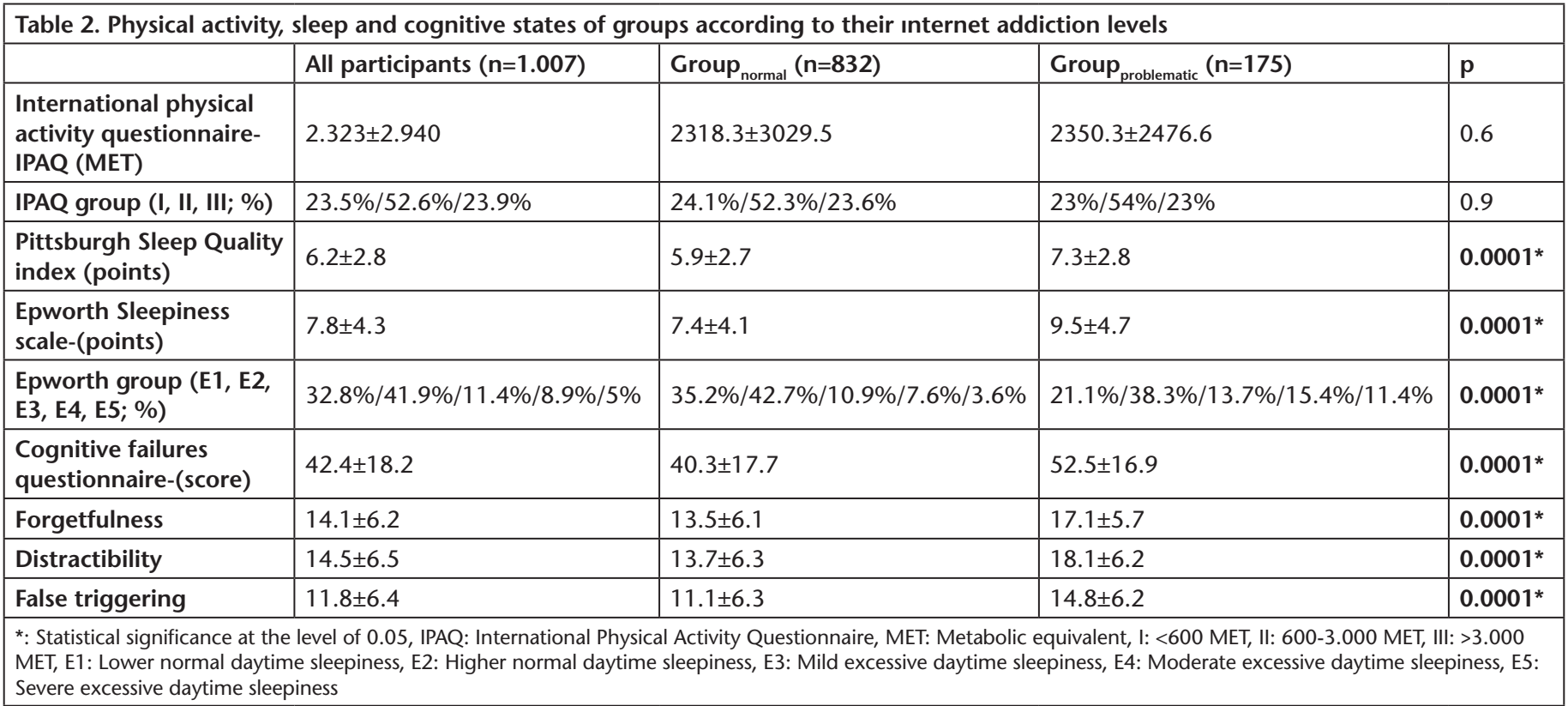


Students received a mean score of $38.4 \pm 12.3$ from the Internet Addiction test. While $82.6 \%(n=832)$ of the students are "normal internet users" with a score of $33.9 \pm 7.4,17.4 \%$ ( $n=175$; sometimes, $n=171$, often, $n=4$ ) are "problematic internet users" with a score of 59.3 \pm 8.6 .

The score of the PSQI is $6.2 \pm 2.8$, and the score of the ESS is 7.8 \pm 4.3 . In the ESS, there is no presence of sleepiness in $32.8 \%(n=330)$ of the students; however, $41.9 \%(n=422)$ have increased daytime sleepiness, $11.4 \%(n=115)$ have mild daytime sleepiness, $8.9 \%(n=90)$ have moderate daytime sleepiness, and $5 \%(n=50)$ have severe daytime sleepiness (Table 2$)$.

The mean score obtained from the CFQ is $42.4 \pm 18.2$. The subdimension scores of the scale were calculated to be $14.1 \pm 6.2$ in forgetfulness, $14.5 \pm 6.5$ in distractibility, and 11.8 \pm 6.4 in false triggering (Table 2).

When the students were divided into two groups as Group ${ }_{\text {normal }}$ and Group problematic according to their levels of internet addiction, a difference was found in terms of Body Mass index, gender, smoking and regular alcohol consumption (Table 1), sleep quality, sleepiness and cognitive status (Table 2$),(p<0.05)$.

When we examine the differences in physical activity, sleep, and cognitive status among the groups, the scores obtained by female gender participants are higher in the data than male gender, except for the score obtained from the Internet Addiction test and the MET values indirectly measured from IPAQ-short form. The high score obtained from these female gender questionnaires was not found statistically significant only at the PSQI scores in Group problematic (Table 3).

A positive, low-level correlation was detected between the score of the Internet Addiction test score and Body Mass index $(p=0.0001, r=0.1)$, male gender $(p=0.0001, r=0.2)$, smoking $(p=0.0001, r=0.1)$ and alcohol consumption $(p=0.001, r=0.1)$, the score of the ESS ( $p=0.0001, r=0.3)$, the score of the PSQI $(p=0.0001, r=0.2)$, the total and subdimension scores of the CFQ $(p=0.0001, r=0.3)$, (Table 4).

Table 3. Physical activity, sleep and cognitive states of groups according to gender

\begin{tabular}{|c|c|c|c|c|c|c|}
\hline & \multicolumn{2}{|c|}{$\operatorname{Group}_{\text {normal }}(\mathrm{n}=\mathbf{8 3 2})$} & \multirow[b]{2}{*}{ p } & \multicolumn{2}{|c|}{$\operatorname{Group}_{\text {problematic }}(\mathrm{n}=175)$} & \multirow[b]{2}{*}{$\mathrm{p}$} \\
\hline & Female $(n=536)$ & Male $(n=296)$ & & Female $(n=83)$ & Male $(n=92)$ & \\
\hline Internet Addiction test (score) & $33.5 \pm 7.3$ & $34.7 \pm 7.6$ & $0.03^{*}$ & $58.4 \pm 8.3$ & $60.2 \pm 8.8$ & 0,2 \\
\hline PSQI (points) & $6.1 \pm 2.7$ & $5.7 \pm 2.8$ & $0.03^{*}$ & $7.6 \pm 2.7$ & $7.0 \pm 2.9$ & 0.2 \\
\hline ESS (points) & $8.0 \pm 4.2$ & $6.3 \pm 3.6$ & $0.0001^{*}$ & $10.6 \pm 4.7$ & $8.5 \pm 4.6$ & $0.003^{*}$ \\
\hline CFQ-forgetfulness & $14.2 \pm 6.2$ & $12.3 \pm 5.9$ & $0.0001^{*}$ & $19.1 \pm 5.5$ & $15.3 \pm 5.3$ & $0.0001^{*}$ \\
\hline CFQ-distractibility & $14.2 \pm 6.4$ & $12.7 \pm 6.1$ & $0.001^{*}$ & $20.0 \pm 5.9$ & $16.4 \pm 6.0$ & $0.0001^{*}$ \\
\hline CFQ-false triggering & $11.9 \pm 6.2$ & $9.7 \pm 6.2$ & $0.0001^{*}$ & $17.0 \pm 5.9$ & $12.9 \pm 5.8$ & $0.0001^{*}$ \\
\hline
\end{tabular}

*: Statistical significance at the level of 0.05, IPAQ: International Physical Activity Questionnaire, MET: Metabolic equivalent, PSQI: Pittsburgh Sleep Quality index, ESS: Epworth Sleepiness scale, CFQ: Cognitive Failures Questionnaire

\begin{tabular}{|c|c|c|}
\hline & & \\
\hline Body Mass index & $\mathrm{p}$ & $0.0001^{*}$ \\
\hline \multirow{2}{*}{ Male gender } & $\mathrm{p}$ & $0.0001^{*}$ \\
\hline & $r$ & 0.2 \\
\hline Smoking & $\mathrm{p}$ & $0.0001^{*}$ \\
\hline \multirow{2}{*}{ Alcohol consumption } & $\mathrm{p}$ & $0.0001^{*}$ \\
\hline & $r$ & 0.1 \\
\hline \multirow{2}{*}{ Epworth Sleepiness scale score } & $\mathrm{p}$ & $0.0001^{*}$ \\
\hline & $r$ & 0.3 \\
\hline Pittsburgh Sleep Quality index score & $\mathrm{p}$ & $0.0001^{*}$ \\
\hline
\end{tabular}


Body Mass index, male gender, smoking, low sleep quality and high sleepiness influence the scores of the Internet Addiction test $(p=0.0001, F=27.7)$.

\section{Discussion}

The Internet is a new exciting communication tool that has become an indispensable part of daily life worldwide. However, the excessive use of internet technology for different purposes other than searching for information, social interaction, and commercial operations has led to the frequent incidence of internet addiction in societies. In our study, there are $17.4 \%$ of participants who received 50 and above from the Internet Addiction test and $82.6 \%$ of participants who received a score lower than 50. When the literature is reviewed, it is observed that $40 \%$ of the participants received 50 and above from the Internet Addiction test in a study conducted on 587 students with the same scale abroad (29). In two different studies carried out with university students in our country, $7.7 \%$ of participants in one of the studies (30) and $22.9 \%$ of participants in the other study (31) received a score of 50 and above. The differences in the dates and places of the studies, sociodemographic characteristics of the participants, and the methodological differences of the studies can be shown as the reasons for these percentage differences.

In an epidemiological study, in which the correlation between internet addiction and gender was examined, internet addiction was reported to be observed at a statistically higher rate in men, as in our study (32). This statistically high rate in men may result from the fact that they use virtual gambling, virtual games, and social media at a higher level compared to women. Furthermore, in another study conducted with 1.879 students in 2012, no statistically significant difference was found between female and male genders with respect to internet addiction (33).

In a study conducted by Greenberg et al. (34), it was reported that the rates of alcohol and other substance addictions were higher in people with internet addiction. In a study conducted in Norway, a low correlation was detected between other addiction types such as alcohol and tobacco and internet addiction in young people (35). In another study, it was revealed that internet addicts among 2.336 high school students had more problems with alcohol consumption; however, no correlation was found between smoking and internet addiction (36). In our country, in a study including 2.096 university students, a statistically significant difference was detected, similarly to our study, between the groups when the groups with and without internet addiction were compared in terms of smoking and alcohol consumption (37). As a result of these findings, the co-emergence of excessive internet use, problematic alcohol consumption, and smoking addiction strengthens the idea that similar physiological pathways are influential. The results of our study support this hypothesis.

When the physical activity levels of the participants were examined, no statistically significant difference was found in the results of the IPAQ-short form between the groups with normal and problematic internet use. In a study published in 2018 and conducted on adolescents and young people in Vietnam, no statistically significant correlation was determined between the problematic internet use and physical activity levels, similarly to our study (38). However, in our study, statistically higher Body Mass index values were found in the group with problematic internet use compared to the group with normal internet use. In a study conducted with 2.467 students in 2013, Bener and Bhugra (39). collected data on obesity and the duration of internet use. They concluded that adolescents with the Body Mass index above the normal value spent more than 3 hours on the Internet when compared to their normal peers (39). In another study, 2.105 university students were evaluated, and it was found out that internet use was higher in students with a high Body Mass index (40).

The time spent in front of any screen may negatively affect a person's preparation process for sleeping. Light and sound that come from the screens of tools such as computers, tablets, and mobile phones keep users awake and may affect the secretion of hormones such as melatonin, which helps with sleeping. This process may disrupt the sleep rhythm of an individual, delay falling asleep, shorten the remaining time for sleep, and impair sleep quality by causing periodical awakening during sleep. The correlation between sleep disorders and internet addiction has attracted the attention of many researchers in recent years. Considering the answers given to both sleep quality evaluation scales used in our study, the mean score of the group, including problematic internet users, is statistically significantly higher than the mean score of the group, including normal internet users. In the literature, there are some studies investigating the correlation between internet addiction and sleep quality. A study conducted on university students in Taiwan revealed that sleep quality was 1.4 times worse in students with internet addiction than students without internet addiction (41). In another study conducted on university students in Canada, a positive correlation was demonstrated between internet addiction and poor sleep quality (42). In another study on university students, it was found that the mean scores of the internet addiction scale in students with a sleep disorder were higher compared to the group without sleep disorder (43). Furthermore, addicted internet users often experience time management problems. When this situation is combined with individuals' habits of staying online until late hours at night, it may result in extreme fatigue, sleeplessness the next day, and, thus, adverse outcomes in academic and professional areas $(36,44,45)$.

In daily life, most people suffer from the lack of attention and forgetfulness. It is known that these problems may have relatively simple results, such as forgetting what to buy from the supermarket or forgetting the keys while leaving home as well as more negative outcomes for professionals such as a surgeon or a public transportation driver. As a result of the increasing digital technological developments over the last twenty years, Internet technology has become a widely used tool across the world. The increasing studies conducted to identify whether there is a correlation between internet use and cognitive status disorders are gaining significance. When the literature was 
reviewed, it was found in a study carried out in 2013 that the mean score received by the group with addictive internet use from the CFQ was significantly higher than the mean score of the group without internet addiction (46). In another study conducted with 210 participants, a significant correlation was found between mobile phone and internet use and the increased CFQ score (47). A positive, low-level correlation was detected between problematic internet use and the total and subdimension scores of the CFQ in our study, similarly to the literature.

\section{Study Limitations}

The examination of students studying only at one university, not evaluating the eating habits likely to affect the Body Mass index, and not indicating the different sleep patterns of students, who receive evening education at our university and are included in our study, as a factor can be shown as the limitations of our study.

\section{Conclusion}

Our study has shown that problematic internet use is correlated with low sleep quality, cognitive problems experienced in daily life, and high Body Mass index in university students. Furthermore, internet addiction is accompanied by addictive habits such as smoking and alcohol consumption. Internet addiction in young people is a subject that should be attached great importance for the future of a society. The presence of internet addiction and its possible effects should also be investigated in different cultures and age groups, and the studies on the prevention of its negative effects should be focused on.

\section{Ethics}

Ethics Committee Approval: The study was approved at the meeting of the local ethics committee dated 28/11/2019 and with decision number 283.

Informed Consent: Informed consent form was obtained from all participants included in our study.

Peer-review: Internally peer-reviewed.

\section{Authorship Contributions}

Concept: S.E., C.Ç., Design: S.E., C.Ç., Data Collection or Processing: H.T.A., E.A., A.C., A.O., Analysis or Interpretation: S.E., H.T.A., Literature Search: S.E., H.T.A., Writing: H.T.A.

Conflict of Interest: No conflict of interest was declared by the authors.

Financial Disclosure: The authors declared that this study received no financial support.

\section{References}

1. Kalaman S, Bat M. Internet addiction and media usage: A study about undergraduate students. J Int Soc Res 2016;9:878-85.

2. Evcılı F, Yurtsever I. Problematic internet use, sleep quality and academic achievement in Turkish university students. Adolesc Psychiatr 2018;8:185-94.

3. Chi X, Hong X, Chen X. Profiles and sociodemographic correlates of internet addiction in early adolescents in southern China. Addict Behav 2020;106:106385.
4. Mendoza JA, Zimmerman FJ, Christakis DA. Television viewing, computer use, obesity, and adiposity in US preschool children. Int J Behav Nutr Phys Act 2007;4:44.

5. Ying Ying C, Awaluddin SM, Kuang Kuay L, Siew Man C, Baharudin A, Miaw Yn L, Sahril N, Omar MA, Ahmad NA, Ibrahim N. Association of internet addiction with adolescents' lifestyle: a national schoolbased survey. Int J Environ Res Public Health 2020;18:168.

6. Chakraborty R, Bose K, Khongsdier R, Bisai S. Body mass index and body fat among adult Bengalee male slum dwellers in West Bengal, India. Obes Res Clin Pract 2009;3:141-8.

7. Górnicka M, Hamulka J, Wadolowska L, Kowalkowska J, Kostyra E, Tomaszewska M, Czeczelewski J, Bronkowska M. Activity-inactivity patterns, screen time, and physical activity: the association with overweight, central obesity and muscle strength in Polish teenagers. report from the $A B C$ of healthy eating study. Int J Environ Res Public Health 2020;17:7842.

8. Dennison BA, Erb TA, Jenkins PL. Television viewing and television in bedroom associated with overweight risk among low-income preschool children. Pediatrics 2002;109:1028-35.

9. Gómez SF, Homs C, Wärnberg J, Medrano M, Gonzalez-Gross M, Gusi N, Aznar S, Cascales EM, González-Valeiro M, Serra-Majem L, Terrados N, Tur JA, Segú M, Lassale C, Benavente-Marín JC, Labayen I, Zapico AG, Sánchez-Gómez J, Jiménez-Zazo F, Alcaraz PE, Sevilla-Sanchez M, Herrera-Ramos E, Pulgar S, Bibiloni MDM, Sancho O, Schröder H. Study protocol of a population-based cohort investigating physical activity, sedentarism, lifestyles and obesity in Spanish youth: the PASOS study. BMJ Open 2020;10:e036210. doi: 10.1136/bmjopen-2019-036210

10. Fitzgerald SJ, Kriska AM, Pereira MA, De Courten MP. Associations among physical activity, television watching, and obesity in adult Pima Indians. Med Sci Sport Exer 1997;29:910-5.

11. Van den Bulck J. Television viewing, computer game playing, and internet use and self-reported time to bed and time out of bed in secondary-school children. Sleep 2004;27:101-4.

12. Barion A, Zee PC. A clinical approach to circadian rhythm sleep disorders. Sleep Med 2007;8:566-77.

13. Peltzer K, Pengpid S. Nocturnal sleep problems among university students from 26 countries. Sleep Breath 2015;19:499-508.

14. Karimy M, Parvizi F, Rouhani MR, Griffiths MD, Armoon B, Fattah Moghaddam L. The association between internet addiction, sleep quality, and health-related quality of life among Iranian medical students. J Addict Dis 2020;38:317-25.

15. Zachariae R, Lyby MS, Ritterband LM, O'Toole MS. Efficacy of internet-delivered cognitive-behavioral therapy for insomni--a systematic review and meta-analysis of randomized controlled trials. Sleep Med Rev 2016;30:1-10.

16. Saquib J. Internet addiction among Saudi Arabian youth. Int J Health Sci (Qassim) 2020;14:1-2.

17. Shapira NA, Goldsmith TD, Keck Jr PE, Khosla UM, McElroy SL. Psychiatric features of individuals with problematic internet use. J Affect Disord 2000;57:267-72.

18. Park MH, Park EJ, Choi J, Chai S, Lee JH, Lee C, Kim DJ. Preliminary study of Internet addiction and cognitive function in adolescents based on IQ tests. Psychiatry Res 2011;190:275-81.

19. Unsworth N, McMillan BD, Brewer GA, Spillers G). Everyday attention failures: an individual differences investigation. J Exp Psychol Learn Mem Cogn 2012;38:1765-72.

20. Young KS. Internet addiction: The emergence of a new clinical disorder. Cyberpsychol Behav 1998;1:237-44. 
21. Ngai SS. Exploring the validity of the internet addiction test for students in grades 5-9 in Hong Kong. Int J Adolesc Youth 2007; 13:221-37.

22. Committee IR. Guidelines for data processing and analysis of the International Physical Activity Questionnaire (IPAQ)-short and long forms. Available from: http://www.ipaq.ki.se/scoring.pdf 2005.

23. Saglam M, Arikan H, Savci S, Inal-Ince D, Bosnak-Guclu M, Karabulut E, Tokgozoglu L. International physical activity questionnaire: reliability and validity of the Turkish version. Percept Mot Skills 2010;111:278-84.

24. Öztürk M. Üniversitede eğitim-öğretim gören öğrencilerde uluslararası fiziksel aktivite anketinin geçerliliği ve güvenirliği ve fiziksel aktivite düzeylerinin belirlenmesi. Yayımlanmamış Yüksek Lisans Tezi, Ankara: Hacettepe Üniversitesi 2005.

25. Izci B, Ardic S, Firat H, Sahin A, Altinors M, Karacan I. Reliability and validity studies of the Turkish version of the Epworth Sleepiness Scale. Sleep Breath 2008;12:161-8.

26. Buysse DJ, Hall ML, Strollo PJ, Kamarck TW, Owens J, Lee L, Reis $\mathrm{SE}$, Matthews KA. Relationships between the Pittsburgh Sleep Quality Index (PSQI), Epworth Sleepiness Scale (ESS), and clinical/ polysomnographic measures in a community sample. J Clin Sleep Med 2008;4:563-71.

27. Broadbent DE, Cooper PF, FitzGerald P, Parkes KR. The cognitive failures questionnaire (CFQ) and its correlates. $\mathrm{Br} J$ Clin Psychol 1982;21:1-16.

28. Ekici G, Uysal SA, Altuntaş O. The validity and reliability of cognitive failures questionnaire in university students. Turk J Physiother Rehabil 2016;27:55-60.

29. Al-Gamal E, Alzayyat A, Ahmad MM. Prevalence of internet addiction and its association with psychological distress and coping strategies among university students in Jordan. Perspect Psychiatr Care 2016;52:49-61.

30. Gunay O, Ozturk A, Arslantas EE, Sevinc N. Internet addiction and depression levels in Erciyes University students. Dusunen Adam 2018;31:79-88.

31. Aslan E, Yazıcı A. Internet addiction among university students and related sociodemografic factors. J Clin Psychol 2016;19:109-17.

32. Bakken IJ, Wenzel HG, Götestam KG, Johansson A, Øren A. Internet addiction among Norwegian adults: a stratified probability sample study. Scand J Psychol 2009;50:121-7.

33. Carbonell X, Chamarro A, Griffiths M, Oberst U, Cladellas R, Talarn A. Problematic internet and cell phone use in Spanish teenagers and young students. An de Psicol 2012;28:789-96.

34. Greenberg JL, Lewis SE, Dodd DK. Overlapping addictions and self-esteem among college men and women. Addict Behav 1999;24:565-71.

35. Johansson A, Götestam KG. Internet addiction: characteristics of a questionnaire and prevalence in Norwegian youth (12-18 years). Scand J Psychol 2004;45:223-9.
36. Choi K, Son H, Park M, Han I, Kim K, Lee B, Gwak H. Internet overuse and excessive daytime sleepiness in adolescents. Psychiatry Clin Neurosci 2009;63:455-62.

37. Alaçam H, Ateşci $F C$, Şengül AC, Tümkaya $S$. The relationship between smoking and alcohol use and internet addiction among the university students. Anadolu Psikiyatri Derg 2015;16:383-8.

38. Dang AK, Nathan N, Le QNH, Nguyen LH, Nguyen HLT, Nguyen CT, Do HP, Nguyen THT, Tran TT, Nguyen TA. Associations between internet addiction and physical activity among Vietnamese youths and adolescents. Child Youth Serv Rev 2018;93:36-40.

39. Bener A, Bhugra D. Lifestyle and depressive risk factors associated with problematic internet use in adolescents in an Arabian Gulf culture. J Addict Med 2013;7:236-42.

40. Yıldız Ü. Üniversite öğrencilerinde obezite oluşumunda internet bağımlılı̆ının etkisinin saptanması. Uzmanlık Tezi İmir: Dokuz Eylül Üniversitesi; 2014.

41. Cheng SH, Shih CC, Lee IH, Hou YW, Chen KC, Chen KT, Yang YK, Yang YC. A study on the sleep quality of incoming university students. Psychiatry Res 2012;197:270-4.

42. Younes F, Halawi G, Jabbour H, El Osta N, Karam L, Hajj A, Khabbaz LR. Internet addiction and relationships with insomnia, anxiety, depression, stress and self-esteem in university students: A crosssectional designed study. PloS One 2016;11:e0161126. doi: 10.1371/journal.pone.0161126.

43. Demirci A, Doğan R, Matrak Y, Kuruoğlu E, Mevsim V. The effect of problematic Internet use on the sleep quality of medical students. TJFMPC 2015;9:143-9.

44. Punamäki RL, Wallenius $M$, Nygård $C H$, Saarni L, Rimpelä A. Use of information and communication technology (ICT) and perceived health in adolescence: the role of sleeping habits and waking-time tiredness. J Adolesc 2007;30:569-85.

45. Thomée S, Eklöf M, Gustafsson E, Nilsson R, Hagberg M. Prevalence of perceived stress, symptoms of depression and sleep disturbances in relation to information and communication technology (ICT) use among young adults-an explorative prospective study. Comput Human Behav 2007;23:1300-21.

46. Ali AZ, Nisa U. Cognitive failures and internet addiction among university students: an exploratory study. Pak J Psychol 2013;44:111-21.

47. Hadlington L. Cognitive failures in daily life: Exploring the link with Internet addiction and problematic mobile phone use. Comput Human Behav 2015;51:75-81. 